\title{
SADYZM W NAGIM SADZIE. PERWERSJA JAKO STRUKTURA POLSKOŚCI
}

\author{
ZBIGNIEW JAZIENICKI, JAN POTKAŃSKI
}

\begin{abstract}
Abstrakt: Pierwsza część artykułu poświęcona jest perspektywie zastosowania psychoanalitycznej kategorii perwersji - zrekonstruowanej głównie na podstawie pism Jacques'a Lacana i Gillesa Deleuze'a - do analizy patologii polskiej zbiorowej psychiki, jakie wytykają w swoich książkach Jan Sowa, Andrzej Leder i Jarosław Marek Rymkiewicz. Naszym zdaniem kulturowy model Polaka to właśnie perwert, zależnie od pozycji klasowej sadysta albo masochista, nie zaś psychotyk albo edypalny neurotyk. Kategoria perwersji pozwala wyjaśnić dwuznaczną relację polskości do państwa i prawa, która nie jest ani ich prostym odrzuceniem (jak psychoza), ani jednoznaczną afirmacja (jak nerwica). Struktura perwersji - rozpiętej zewnętrznie między nerwicą a psychozą, a wewnętrznie między masochizmem a sadyzmem - pozwala modelować dynamikę współczesnych polskich konfliktów ideologicznych i politycznych, w tym napięcie między akcentowaniem narodowej suwerenności a postkolonialnym odwoływaniem się do wzorów obcych.

Części druga i trzecia to studia przypadków: zbiorowej psychiki bohaterów prozy eseistycznej Rymkiewicza oraz indywidualnej - Nagiego sadu Wiesława Myśliwskiego. Zestawienie to pozwala ukazać odmienność postrzegania tego samego fenomenu - sadyzmu - z wnętrza psychiki, która z pozycją perwersyjną afirmatywnie się identyfikuje (Rymkiewicz), oraz ze zdystansowanej perspektywy neurotyka (Myśliwski), zarazem jednak uchwycić izomorfizm struktur, które kryją się za tymi tak odmiennymi przedstawieniami.
\end{abstract}

Słowa kluczowe: Wiesław Myśliwski, Jarosław Marek Rymkiewicz, Jacques Lacan, Gilles Deleuze, psychoanaliza, perwersja, sadyzm, prawo 


\section{Dynamika osobowości perwersyjnej}

Jednym z najważniejszych toposów współczesnego myślenia o polskości jest przekonanie, że Polakom - jako wspólnocie kulturowo-politycznej - czegoś brakuje, który to fakt staje się widoczny w zestawieniu z silnymi zarówno kulturową, jak i polityczną tradycją narodami zachodnioeuropejskimi (tak naprawdę bezdyskusyjne przykłady można by podać chyba tylko dwa: tradycje Francji i Anglii). Motyw ten wiąże tak ważne i głośne książki, jak Fantomowe ciało króla Jana Sowy, Prześniona rewolucja Andrzeja Ledera i Wieszanie Jarosława Marka Rymkiewicza. O ile socjalizm pierwszego i liberalizm drugiego łączą jeszcze jakieś wspólne dążenia, o tyle trzeci zdaje się zajmować przeciwny biegun politycznego spektrum - a jednak podporządkowuje swoją doktrynę temu samemu schematowi, co jego dwaj polityczni przeciwnicy: dla wszystkich trzech Polakom zabrakło (nierozstrzygnięte - w pewnym okresie historycznym czy po dziś dzień?) prawdziwego polityczno-państwowego upodmiotowienia, które włączyłoby ich w Dzieje czy Historię pisane wielką litera - czy to za pośrednictwem Króla (prawdziwego, a nie elekcyjnego pra-prezydenta), czy też Rewolucji, która by takiego Króla (realnego jeszcze lub już tylko symbolicznego) obaliła - co stanowi dwie strony tej samej monety, jak bowiem co najmniej od czasów Frazera wiemy, przeznaczeniem Króla jest umrzeć w ofierze za symboliczną wieczność swojej władzy, choćby przeniesionej do sfery platońskiej abstrakcji (jak właśnie stało się w państwach-ideałach: wspomnianych wyżej Anglii i Francji). Co istotne: brakuje nam właśnie prawdriwego upodmiotowienia, a nie jego cech w ogóle - polskość to nie jakaś zupełna egzotyka ludu pierwotnego czy barbarzyńskiego, tylko dość wierna imitacja centrum cywilizacji - prawie udana, ale jednak nie do końca.

Analizując słabość polskości, Leder swobodnie, a Sowa bardziej technicznie nawiązują do psychoanalizy Jacques'a Lacana. W jej kontekście słabość owa jawi się jako psychoza: wykluczenie Imienia Ojca, skutkujące nieposzanowaniem królewskiej władzy i prawa jako społecznej gramatyki. Sowa explicite używa tej kategorii (Sowa 2011, 407-409), Leder wykorzystuje ją implicite, utożsamiając ,imaginarium” i ,pole symboliczne” (Leder 2014, 11, 29-33) - o ile zaś u lacanowskiego neurotyka, podległego Imieniu Ojca, wyobrażeniowe (l'imaginaire) i symboliczne (le symbolique) ostro się sobie przeciwstawiają, o tyle psychoza oznacza właśnie brak takiego rozróżnienia. Przypisanie Polakom psychozy w roli kulturowo standardowej struktury podmiotowości rodzi jednak znaczące problemy: psychoza jako całkowite wykluczenie mechanizmów swoistych dla symboliczności na tyle upośledza myślenie, że trudno sobie wyobrazić, aby psychotyczna co do zasady klasa polityczna - jaka miałaby być np. przedrozbiorowa szlachta u Sowy - przez dłuższy czas w miarę jednak sprawnie (choć niesprawiedliwie) zarządzała państwem, upadającym dopiero w dalszej perspektywie. Psychotyk, owszem, imituje symbolicznie sprawnego neurotyka, czyniąc to 
jednak czysto wyobrażeniowo, bez zrozumienia mechanizmów, jest w tej imitacji nieporadny i funkcjonuje społecznie w miarę dobrze jedynie podporządkowany nadzorowi, nie może więc skutecznie sprawować żadnych funkcji władczych. Nie wydaje się także, abyśmy my Polacy współcześni - w skali masowej byli psychotykami, wymagałoby to więc założenia jakiejś narodowej przemiany po drodze. Zarówno Sowa, jak i Leder zdają się wprawdzie sugerować coś w tym stylu - że częściowe przynajmniej „unowocześnienie” (tj. „odpsychotyzowanie”) polskości nastapiło pod wpływem zewnętrznej przemocy, odgrywającej rolę edypalnego ojca - w czasie zaborów (Sowa 2011, 421-430, 526) lub po upadku II Rzeczypospolitej (Leder 2014, 7), zważywszy jednoznaczne potępienie owych przemocy w narodowej mitologii trudno jednak uznać, że ustanowiły one proste przejście od psychozy do nerwicy, skoro w tej ostatniej ojcowskie prawodawstwo winno być bezdyskusyjnie uznane, nawet jeśli narzeka się na jego surowość.

$\mathrm{Na}$ koniec rozbudowanych rozważań o psychozie Sowa jednym zdaniem sugeruje hipotezę alternatywna: „Pozycję, jaką w tej konfiguracji zajmowała szlachta, zinterpretować można również jako perwersyjną" (Sowa 2011, 409). Perwersja to „wyłączony środek” psychoanalizy: typ osobowości, o którym niby wie się, że istnieje, mało kto jednak serio bierze go pod uwagę. Klasyczne wyjaśnienie kliniczne jest proste: osobowość perwertów sprawia, że są z reguły usatysfakcjonowani swoją egzystencją, rzadko więc wybierają się do terapeuty - jeśli już, to zmuszeni przez osoby trzecie lub wręcz przez wymiar sprawiedliwości. Z tego, że mało perwertów spotkać można na kozetce, nie wynika jednak, że równo mało jest ich w społeczeństwie. Nasza teza jest przeciwna: to właśnie kategoria perwersji - a nie psychozy - stanowi klucz do zrozumienia cywilizacyjnych deficytów polskości. Nasz model perwersyjności stanowi przy tym syntezę przedstawionego przez Jacques'a Lacana (Lacan 1989, 1997) - zwłaszcza w rekonstrukcji, jaką zaproponował Bruce Fink (Fink 2002, 234-286) - oraz tego z pism Gilles'a Deleuze'a (Deleuze 1989), syntezę o tyle naturalną, że Lacan i Deleuze przy różnych okazjach explicite ze sobą dialogują, obaj też odwołują się do tradycji freudowskiej, zarazem jednak patrzą na problem z nieco innych perspektyw - o ile wśród perwersji główny przedmiot zainteresowania Deleuze’a to masochizm, Lacan (i za nim Fink) koncentruje się raczej na sadyzmie, nas zaś w szczególności interesuje właśnie relacja tych dwóch biegunów.

Perwersja to w sensie ścisłym stan pośredni między psychozą a nerwicą. Nie jakaś autonomiczna trzecia struktura, trzeci wierzchołek trójkąta równobocznego, jak to czasem bywa ujmowane, lecz bycie pomiędzy i oscylacja między biegunami: inaczej niż psychotyk, perwert przyjmuje do wiadomości ojcowskie prawo i ustanawiająca je kastrację, inaczej jednak niż neurotyk nie traktuje ich całkiem serio, tylko prowadzi z nimi ironiczna grę. Masochista to ten, który wśród perwertów jest prawie-neurotykiem, boi się jednak ofiarowującego mu się zdrowia i właśnie dlatego imitacyjnie zwraca się w stronę psychozy jako oferującej chorobliwą 
„wolność" od ojcowskiego prawodawstwa; sadysta przeciwnie - jest prawie-psychotykiem, pragnąc jednak uniknąć szaleństwa sensu stricto, imitacyjnie wymusza istnienie quasiedypalnego prawa, naśladując jednak tylko jego literę, a nie ducha. Także ucieczka masochisty w stawanie-się-psychotykiem nie oznacza całkowitego wymazania prawa, lecz - jak to analizuje Deleuze - zastapienie edypalnego prawa ojcowskiego prawem fantazmatycznie matriarchalnym, matczynym, którego egzekutorką w przypadku masochizmu stricte seksualnego ma być domina (Deleuze 1989, 57-68, 81-90), będąca wszakże tylko imitacją wszechogarniającej matki psychotyka, a nie jej realnym wcieleniem (niemniej tłumaczy to, czemu z historycznego dystansu zachowania naznaczone taką perwersja mogą się błędnie wydawać naprawdę psychotyczne, jak w zasadniczej interpretacji Sowy). Właśnie ten model zdaje się najbliższy habitusowi polskich szlacheckich elit: perwersyjnie broniąc - jak to opisuje Sowa - „źrenicy wolności” przed wszelkim ograniczeniem, czyli kastracją, ze strony własnego rządu, a zatem odrzucając edypalną suwerenność prawa miejscowego, bez większego oporu poddały się suwerenności „innej”, zaborczej - w szczególności Katarzyny II (jednej z ulubionych bohaterek historycznych Leopolda von Sacher-Masocha) (Chernetsky 2008, 482), której asymetryczny związek ze Stanisławem Poniatowskim wyobrażany jest niemal dosłownie jako podporządkowanie masochisty dominie (ostatnio schemat ten odżył w fantazjach o relacjach łączących Donalda Tuska z Angelą Merkel). Tę samą topikę stosuje się do elit współczesnych i to w znacznej mierze niezależnie od opcji politycznej - masochistyczną uległość wobec innej, „matriarchalnej” suwerenności można widzieć i w podporządkowaniu polskiego państwa Unii Europejskiej, i Ameryce, i Kościołowi, Matce naszej, i rynkom finansowym, i abstrakcyjnej ekonomii; schemat wykracza zresztą poza politykę - elity intelektualne tak samo podporządkowują się dyskursom i modom importowanym z kulturowej centrali, w swoistym konstruktywizmie, który służenie wybranemu dyskursowi ceni wyżej niż rozumienie rzeczywistości. Łącznie ten system podporządkowań można wpisać w przywoływaną przez Sowę kategorię postkolonializmu (Sowa 2011, 431-485), co ułatwia wyjaśnienie nieporozumień, jakie budzi oksymoroniczne z pozoru określenie elit władzy jako masochistycznych - masochiści bowiem, tak jak elity postkolonialne, są ulegli wyłącznie wobec swej mniemanej dominy, wobec osób trzecich jak najbardziej moga być natomiast podmiotami silnymi, przymuszającymi do współudziału w matriarchalnym kulcie.

Masochizm elit odbija się w krzywym zwierciadle ludowego sadyzmu: pragnienia, by jakiś schmittowski suweren wreszcie „zrobił porządek” z całą tą demoralizacją i przykładnie ukarał winnych (tym bardziej, że zwrot masochisty ku dominującym kobietom - realnym bądź metaforycznym - kojarzy się sadyście z psychoza, od której próbuje uciec). Wbrew własnemu mniemaniu pragnienie to jednak jest tylko pokraczną imitacja autentycznego prawa jako rozumu wspólnoty, a nie jego realizacja; w obraz edypalnego ojca, którego chce 
wskrzesić na przekór masochistom, wpisuje wiele z psychozy, przed którą samo ucieka iw efekcie konstruuje ojca paranoicznego jako ekwiwalent schizofrenicznej matki (ten właśnie mechanizm szczegółowo badamy w analitycznej części niniejszego artykułu, masochizmowi zamierzając poświęcić osobna publikację). Sprawia to, że dystans między biegunami zwiększa się na skutek dodatniego sprzężenia zwrotnego: słysząc od sadysty, że Ojciec to właśnie to, co sadysta proponuje, masochista utwierdza się w swoim odrzuceniu funkcji ojcowskiej - także tej innej, stricte edypalnej i jako takiej emancypacyjnej.

Dokładność, z jaką kategoria perwersji pozwala opisać polskiego ducha, nie przekłada się na jej popularność w polskiej recepcji psychoanalizy - przeciwnie, można raczej odnieść wrażenie, że niemal zupełnie została z tej recepcji wyparta (wskutek oporu przeciw niewygodnej prawdzie?). Sowa ją chociaż mimochodem wspomina, bardziej typowa wydaje się jednak sytuacja taka, jak w recenzji Dominika Suleja z książki Lucji Iwanczewskiej Samoreprezentacje. Sade $i$ Witkacy: „Jak rozumieć to, że kreacje omawianych autorów nie sa psychotyczne i jednocześnie są fundamentalnie psychotyczne? Tego się chyba nie da rozumieć" (Sulej 2012). Wbrew zdumieniu recenzenta, nie jest to wcale szczególnie dziwna sytuacja: jeśli tego bycia-i-niebycia psychotykiem nie rozumieć całkiem dosłownie, jako twardej sprzeczności, tylko jako pewne przybliżenie, otrzymamy szkicową definicję perwersji - co nie dziwi w książce, której jednym z dwóch bohaterów jest markiz de Sade; nawet zresztą i sama sprzeczność jakoś się w strukturze perwersji zawiera: jako charakterystyczne dla psychiki perwerta Freud opisuje „rozszczepienie” świadomości, która pozwala jej zarazem uznawać i nie uznawać jakiegoś kluczowego faktu (prototypowo: matczynej „kastracji”) bez popadania w jawny dysonans poznawczy (Freud 2007) - w uproszczeniu można zatem przyjać, że wewnętrznie rozdarta psychika perwerta dzieli się właśnie na neurotyczną (uznająca kastrację) i psychotyczną (przecząca jej) połowę. Ani autorka, ani recenzent kategoria perwersji jednak się nie posługuja, co prowadzi do komunikacyjnego impasu. Trudno im wszakże czynić z tego zarzut, skoro swego czasu zapomniał o perwersji nawet tak wytrawny znawca psychoanalizy, jak Paweł Dybel: recenzując trylogię Czesława Dziekanowskiego o twórczości Wiesława Myśliwskiego, autor dwóch książek o Freudzie ujmuje bohaterów Myśliwskiego i Dziekanowskiego jako z jednej strony uwikłanych wedypalną relację ojca i syna, z drugiej jednak - naznaczonych psychozą, a więc wykluczeniem funkcji ojcowskiej; w konkluzji recenzent uznaje, że ta zrekonstruowana przez Dziekanowskiego struktura psychiczna (trafności rekonstrukcji recenzja nie kwestionuje) to literacka fikcja, nieznana psychoanalitycznej klinice, a wykreowana jako „typ idealny” (nie zaś mimetycznie opisana z życia) dla swoistych celów artystycznych (Dybel 1997, 215). Tymczasem owa rzekoma kreacja to znany nam już sprzecznościowy model perwersji, paradoksalnie, ale całkiem skutecznie łączącej mechanizm edypalny z jego odrzuceniem. Wykluczenie strukturalnej kategorii perwersji przez Dybla jest tym bardziej ostentacyjne, 
że na poziomie fenomenologicznego opisu przypisuje on bohaterom Myśliwskiego (podobnie zresztą jak recenzowany Dziekanowski) zachowania zarówno „sadystyczne” (216), jak i „masochistyczne” (218). Z pozastrukturalnych powodów praktycznych perwersja jest wprawdzie, jak się rzekło, rzadko badana przez psychoanalityków, nie wyklucza to jednak w żadnym razie, by pisarz taki jak Myśliwski mógł ją opisać „z natury”, nie kreując wcale psychiki fikcyjnej.

Skoro polska psychoanaliza teoretyczna jak dotąd z kategorii perwersji nie korzystała w stopniu diagnostycznie zadowalającym, może w poszukiwaniu analiz rodzimego sadomasochizmu warto się zwrócić właśnie ku pisarzom, takim jak Myśliwski? To zresztą standardowy chwyt psychoanalizy i dyskursów nią zainspirowanych: już sam Freud twierdził, że tylko ujął w teoretyczne kategorie to, co pisarze opisali o wiele wcześniej, literatura inspirują się też Lacan i Deleuze, który powieści Sacher-Masocha traktuje tak samo, jak Freud Króla Edypa, a paralelnie Klossowski czy Barthes - pisma Sade’a. W kontekście nawiązań do strukturalizmu podać też można argument niezależny: nie mieliśmy strukturalnej psychoanalizy odpowiadającej dokonaniom Lacana, w literaturoznawstwie polskim strukturalizm rozwinął się natomiast w potężny autonomiczny (a nie imitacyjnopostkolonialny) dyskurs, po dziś dzień stanowiący istotny punkt odniesienia dla swojej dziedziny; inspirowana nim analiza literatury wydaje się więc uprzywilejowanym terenem poszukiwania struktury polskości. Nim jednak przejdziemy do badania materiału wzorcowo literackiego, jakim są powieści, do tego nacechowane miejscami daleko posunięta poetyzacją stylu, rozważmy przypadek pośredni między literaturą a filozoficzno-historycznym piśmiennictwem dyskursywnym: eseistykę poety i literaturoznawcy, wspomnianego już na poczatku Jarosława Marka Rymkiewicza. Zważywszy wspólnote pokoleniową obu naszych bohaterów (Myśliwski - rocznik 1932, Rymkiewicz - 1935), możemy domniemywać, że swoje systemy myślowe stworzyli w odpowiedzi na tę samą sytuację zewnętrzną, ich strukturalne porównanie powinno więc powiedzieć nam coś o strukturze tejże sytuacji.

\section{Suweren-sadysta}

Wobec przyjmujących psychoanalityczną perspektywę analiz Sowy i Ledera analogiczna próba analizy polskiej tożsamości przez Rymkiewicza pozostaje próbą niedocenioną, a w konsekwencji najczęściej ignorowaną. Winą za taką sytuację nie można chyba obarczyć wyłącznie eseistycznego idiomu zdystansowanego wobec teoretycznego ujęcia, w tym od języka psychoanalizy (która jednak w swoim jungowskim wariancie przez krótki moment patronowała debiutanckiej klasycystycznej twórczości poety). O przeoczaniu analitycznego 
potencjału tej eseistyki wydaje się bowiem decydować przede wszystkim jej polityczny ciężar, sprawiający, że o ile Rymkiewicz rozpoznaje idiosynkrazje zbiorowej psychiki równie sprawnie, co Sowa czy Leder, o tyle w przeciwieństwie do nich przynajmniej część tej swoistości opatruje znakiem dodatnim. Diagnostyka w wydaniu wspomnianych autorów ma wymiar krytyczny i emancypacyjny, tymczasem Rymkiewicz nie formułuje nagany ani terapeutycznej korekty, lecz raczej postuluje selekcję: wybór z faktycznie dostępnej polskości tego, co „prawdziwie” polskie, przesłaniajacy wady zbiorowej psyche tonem narodowej dumy. Podobnie jak Sowa, Rymkiewicz przenikliwie ukazuje strukturalną skazę Polski, nie widzi w niej wszakże globalnej dysfunkcji, którą można by wyleczyć tylko holistycznie, lecz lokalne schorzenie, które najlepiej zwalczać amputacją tego, co nie pasuje do ideału. Inaczej też niż autorowi Fantomowego ciała króla, który patologię polskiej szlachty prymarnie związał z lacanowskim modelem psychozy, analizom Rymkiewicza, choć stroniącym od idiomu psychoanalizy, bliższy byłby model perwersji.

Nasza teza brzmi zatem: eseistyka Rymkiewicza stanowi konkurencyjną wobec Sowy i Ledera rekonstrukcję zbiorowej tożsamości jako naznaczonej pierwiastkiem perwersyjnym. Diagnoza ta nie jest przy tym czystą spekulacja, lecz oparta zostaje na bogatym materiale historycznym. To bowiem dopiero w historii materializuje się „duch polski” (Rymkiewicz 1983), poprzez realizacje fantazmatycznych scenariuszy wytwarzający ślady zbiorowej struktury psychicznej. Symptomatyczny jest już sam wybór tematyki, jakiego eseista dokonuje w swoich kolejnych książkach poświęconych historii ojczystej; dotyczą one kolejno wydarzeń zamachu stanu inicjującego powstanie listopadowe (Wielki ksiqże), samosądu podczas insurekcji kościuszkowskiej (Wieszanie), powstania warszawskiego (Kinderszenen), aktu pogwałcenia decyzji króla (Samuel Zborowski) oraz płonnego, acz chwalebnego liberum veto podczas sejmu rozbiorowego (Reytan). Łatwo zauważyć, że wspólnym mianownikiem jest tu negatywny stosunek do porządku zastanego prawa, którego tymczasowe zawieszenie problematyzowane jest uporczywie w kolejnych esejach. Można by wręcz powiedzieć, że lejtmotywem Rymkiewiczowskiej eseistyki, a zarazem polem diagnozy polskości, jest „stan wyjątkowy" - moment zdezaktywowania porządku prawnego, na miejscu którego uruchomiony zostaje porządek sprawniejszy, eliminujący niedomagania „stanu normy”, nieoznaczający jednak psychotycznego wykluczenia prawa w ogóle, lecz demaskację prawa dotychczasowego jako fałszywego, które trzeba zastapić autentycznym, aczkolwiek sam moment zamachu na prawo dotychczasowe uznać można za chwilową aktywizacje psychotycznego aspektu rozszczepionej psychiki perwerta, co u Rymkiewicza często objawia się jako bitewna rzeź albo morderczy dionizyjski tłum. 
Pojęcie stanu wyjątkowego, wyjęte wprost z prawnych koncepcji Carla Schmitta, wydaje się szczególnie adekwatne do interpretacji Rymkiewiczowskiej eseistyki, gdyż kładzie nacisk na rolę narodowego suwerena, który w sytuacji zawieszonego prawa miałby artykułować swoja wolę jako podstawę dla prawa nowego, prawdziwie polskiego. Wyselekcjonowanie przez eseistę aktów destabilizacji porządku władzy - zamachu stanu, insurekcji, powstania, samosądu, rokoszu, „obywatelskiego nieposłuszeństwa” - rzuca zarazem specyficzne światło na jego diagnozę polskości: oto miałaby się ona aktywizować w momencie agresywnej kontestacji wiodącego porządku jako rażąco niefunkcjonalnego i domagającego się natychmiastowej wymiany. Wybór takiej tematyki skrywa przekonanie, że diagnozie polskiej tożsamości najefektywniej służy moment, gdy ta daje o sobie znać w swoim pozaprawnym, wrogim instytucjonalnemu gorsetowi wigorze. Możliwość tę otwiera zaś w sposób najsprawniejszy zaprowadzany „otchłannym aktem decyzyjnym” (Žižek 2011, 29) głębinowego suwerena stan wyjątkowy.

Skoro substancjalna Polska połączona zostaje przez Rymkiewicza z eskalacja przemocy, pojawia się podejrzenie, że jej modusem jest czysta sadystyczna brutalność. Już logika stanu wyjątkowego realizuje sadystyczny schemat: cena, jaka trzeba zapłacić za ustanowienie suwerennej władzy, jest pogwałcenie dotychczasowego porządku prawa, demaskowanego jako legalistyczny pozór sprzeczny z istotą prawomocności. Stan wyjątkowy przynosi jednak obietnicę radykalnej poprawy - walor jego obwieszczenia nie wyczerpuje się $\mathrm{w}$ intruzji w porządek władzy, lecz w jego wymianie na porządek sprawniejszy, lepiej i bardziej bezwzględnie funkcjonujący. Podobnie Lacan w sadystycznej agresji widzi nie tyle obsceniczną przemoc, co staranie o przywrócenie kastracyjnego rygoru, sprowokowanie władzy do działania. Prawo pogwałcone zostaje nie w ramach wendety na opresywnym ojcu, lecz w reakcji na jego impotencję, niezdolność do symbolicznej kastracji, której brak zablokował integrację podmiotu $z$ porządkiem symbolicznym. Perwert nie otrzymuje rozkoszy w związku z samym transgresywnym przekroczeniem zakazu - generuje ja przywrócona moc ojcowskiego prawa w imitacji kastracyjnej przemocy, tj. w podmianie bezsilnego prawa na karnawałowa przemoc stanu wyjattkowego. Prawo to stanowi jednak zawsze ledwie ironiczny poblask skuteczności prawa edypalnego, jako że pełne przywrócenie funkcji ojcowskiej okazuje się niewykonalne.

Analizowane przez Rymkiewicza historyczne przykłady zainstalowania na zgliszczach impotentnego porządku silnej władzy pozostają zgodne z lacanowską logika sadyzmu. Omawiane przez eseistę eksplozje polskości zawsze zatrzymują się na progu ustanowienia/przywrócenia ojcowskiego prawa. Wymownym przykładem dostarczanym przez Wieszanie jest planowana przez polskich jakobinów egzekucja Stanisława Poniatowskiego, blokującego nadejście nowego, nieskorumpowanego porządku politycznego. Polska rewolucja ograniczyła się jednak do niemających istotnych politycznych implikacji 
spontanicznych wieszań narodowych zdrajców - nadejście nowego prawa wyczerpało się w przemocy spontanicznego samosądu. Lacanowska kategoria perwersji podpowiada, że stawka jest tutaj nie rygorystyczne domknięcie nowego, lecz sama czysta, bezproduktywna przemoc imitująca i tym sposobem próbująca przywrócić to, co stare. Perwert wymusza na Innym, by prawo istniało, ale działa ono tylko dopóty, dopóki odgrywane jest ono jako akt przemocy, a nie jako autonomiczne urządzenie, jak w nerwicy. Historia ojczystych stanów wyjątkowych, tworzących tematyczną oś Rymkiewiczowskiej eseistyki, jawi się w tej perspektywie jako katalog symptomów polskiej perwersyjności. Objawia się ona wyłącznie w przemocowej imitacji zapoznanej ojcowskiej dyscypliny, której brak zatrzymuje ja na granicy symbolicznego, wymuszając ciagłe chybotanie na jej linii (sadystyczna kondycja polskości decyduje być może także o jej antymodernizacyjnym wektorze jako skutku tego, że perwert nie może otrzymać satysfakcji w wymiarze symbolicznym, którym wobec tego ostentacyjnie gardzi).

Deficyt edypalnej funkcji ojcowskiej skutkujący niepowodzeniem symbolicznej kastracji Rymkiewicz ilustruje katalogiem słabych ojców. Jego rozważania nad I Rzecząpospolitą pokrywają się pod tym względem z rozpoznaniami Sowy, który rekonstruując psychotyczną kondycję polskiej szlachty, zwrócił uwagę na miejsce króla w jej imaginarium. Szlachcic-psychotyk pragnął według Sowy króla-Ojca jednocześnie doskonałego i martwego (Sowa 2011, 410). W analogiczny sposób, jako władcę martwego, strukturalnie nieobecnego, Rymkiewicz charakteryzuje Stanisława Augusta Poniatowskiego. Patriarchalny układ demokracji szlacheckiej - szlachta-synowie, ojczyzna-Matka i Król-ojciec (określany także jako „małżonek Rzeczypospolitej”) - eseista diagnozuje jako zaburzony właśnie wskutek słabości ojca. Król elekcyjny, obierany przez własnych poddanych, nie dysponuje boskim poruczeniem, które daje rezonujący $z$ edypalnością mechanizm dziedziczenia; jak postmodernistyczny ojciec (według Finka), elekt nie wymaga dyscypliny, lecz doprasza się miłości. Rymkiewicz skrupulatnie wypunktowuje niedomagania władzy Poniatowskiego: brak kompetencji, szacunku poddanych, wreszcie rozwiązłość jako zapowiedź jego stosunku do ojczyzny-żony - jej korupcyjnej zdrady. Nasz teoretyczny model pozwala jednak uściślić, że nie jest to stan sensu stricto psychozy, lecz raczej komplementarnej wobec ludowego sadyzmu perwersji - masochizmu, którym zainfekowany jest nie tylko król, ale $\mathrm{i}$ solidarne $\mathrm{z}$ nim, a podobnie wyalienowane $\mathrm{z}$ narodu elity (w Wieszaniu zidentyfikowane jako pozamykani w podmiejskich dworkach zamożni „obywatele”, odcinający się od patriotycznego i skłonnego do przemocy pospólstwa) (Rymkiewicz 2007, 210-217).

Kiedy faktyczny król nie dysponuje tradycyjnymi kastracyjnymi prerogatywami, usiłuje się go zastapić arbitralnie wybranym „ojcem” silnym, którego pozornie edypalna władza, wyobrażona jako przesadnie surowa, ma zastąpić brakujące prawo w ten sposób, że nadmiar przemocy miałby skompensować deficyt struktury. Znamienne, że w Wielkim 
księciu do funkcji ojcowskiej, w sytuacji politycznej podległości, intronizowany zostaje książę Konstanty. Kuriozalność jego tyrańskiej władzy (piekło urządzane polskim żołnierzom za niedopięte guziki) wyraźnie sygnalizuje, że zastapienie władzy słabego ojca radykalizacją prawnej dyscypliny skończyć się musi spektakularnym niepowodzeniem. Sadystyczna inscenizacja prawa, próba przywrócenia pozycji surowego ojca przemienia się bowiem ostatecznie, jak w Wielkim księciu, w farsowe widowisko. Mimo tego Rymkiewicz nie sympatyzuje z próbą restauracji porządku autentycznie edypalnego, jaką w Wieszaniu reprezentuje Kościuszko - w umiarkowaniu jego dyktatury eseista widzi jedną z przyczyn klęski powstania; większym poparciem autora zdaje się cieszyć dbały o legalność procedur sądowych prezydent Warszawy, Wyssogota-Zakrzewski, ale $i$ on symbolicznie współuczestniczy w ogólnej klęsce, podobnie jak typowany zrazu na fundatora stanu wyjątkowego Kołłątaj.

Rymkiewiczowska afirmacja sadyzmu decyduje o sposobie, w jaki eseistyka poety jest na ogół czytana - nie jako poważny projekt diagnostyczny, lecz raczej jako wyraz radykalnych sympatii politycznych autora. Kontekst „konserwatywnej rewolucji” (Heidegger, Jünger, Schmitt), w którym twórczość tę chętnie się umieszcza, streszcza jednak w najpełniejszy sposób perwersyjne napięcie związane ze stosunkiem do porządku władzy. Apel o zmianę skorumpowanej, impotentnej rzeczywistości politycznej wiąże się z wezwaniem do wieszania - wybuchem kolektywnej przemocy, interpretowanej jako pasja karania zdrajców, wyręczania niesprawnego sądownictwa. Pogarda dla porządku politycznego „pikowanego” figurą słabego ojca/impotentnego prawa przeradza się w pragnienie stanu wyjątkowego, a wraz z nim rządów silnej ręki suwerena, edypalnego hiperbolicznie (tym kontekście należałoby czytać pamiętną odezwę z pierwszej strony Rz̨eczypospolitej: Do Jarosława Kaczynskkiego). Potencjał stanu wyjątkowego jako stawka konserwatywnej rewolucji (etymologia „rewolucji” podpowiada skądinąd, że nakierowana jest ona na powrót, przywrócenie dawnego ładu, nie zaś ustanowienie nowego) (Arendt 2003, 48) odpowiada perwersyjnej jouissance. Jej wyobrażeniowy scenariusz wspomagany jest przez świetnie funkcjonująca w sposobie myślenia konserwatywnych środowisk schmittowską dialektykę formalnych zapisów prawnych i prawa substancjalnego (Schmitt 2015). To w imię tego drugiego - w imię surowego, kastrującego ojca substytuowanego przez przemoc suwerena - domknięty ma być zdominowany dotąd przez matriarchalne pragnienie Matki ( $m$ Other) porządek symboliczny. 


\section{Schizoanaliza wsi}

Jak wynika z powyższej analizy, Rymkiewicz zasadniczo identyfikuje się z sadystycznym aspektem tożsamości perwersyjnej; przypadek Myśliwskiego jest odmienny - pisarz sytuuje się na zewnątrz badanej struktury, opisując ją z dystansu niewielkiego wprawdzie, niemniej krytycznego. Główny wątek Nagiego sadu to relacja syna z ojcem, silna i bez reszty definiująca tożsamość syna-narratora także wtedy, gdy ojciec popada w demencję, a następnie umiera. W kontekście psychoanalizy narzuca się od razu interpretacja takiej relacji jako edypalnej. Niektóre szczegóły z pozoru się zgadzają: Czesław Dziekanowski zwraca np. uwagę, że po chłopsku zmitologizowana ziemia jest symbolem matki, a więc usilne starania powieściowego ojca, by syn nie został rolnikiem i nie pracował na roli można uznać za metaforę kastracyjnej separacji męskiego potomka od żony-matki (Dziekanowski 1990b, 25-29, 41). W porównaniu z klasyczną narracją Freuda „sukces” ojca u Myśliwskiego jest jednak zbyt dusy: edypalny ojciec owszem, separuje od rzeczywistej matki, ale w zamian oferuje jej ekwiwalenty symboliczne (takie właśnie jak ziemia), co ostatecznie prowadzi syna do identyfikacji z ojcem, np. w sferze zawodu (syn chłopa przejmuje jego gospodarstwo itp.), ale też małżeństwa i rodziny (tymczasem syn-narrator pozostaje bezżenny i bezdzietny), i powtórzenia roli ojcowskiej w kolejnym ogniwie cyklu pokoleń. Paralelnie matka rzeczywista po odegraniu biologicznej roli urodzenia i odchowania syna nie tylko zostaje od niego w Nagim sadrie odseparowana, lecz także gwałtownie traci na znaczeniu, by w pewnym momencie prawie dosłownie „zniknąc” (Myśliwski 2011, 167). Akcentowana przez Dziekanowskiego (Dziekanowski 1990a, 37, i 1993, 41, 92) i Dybla (Dybel 1997, 216) symbioza powieściowego syna z ojcem przypomina mechanizm psychotyczny - ten jednak łączy dziecko z matka, nie z ojcem, który w psychozie zostaje zupełnie wykluczony. Omówiona wyżej kategoria perwersji (w szczególności sadyzmu) pozwala pojęciowo ujać to oksymoroniczne z pozoru połączenie nadmiernej edypalności z psychotycznym jej brakiem: sadysta zna edypalność - inaczej niż psychotyk - ale tylko „z widzenia”, jako ideę, której sam nie wciela (inaczej niż neurotyk), obawiając się zatem regresu w psychozę, edypalność tę imituje, lecz jedynie wyobrażeniowo, fragmentarycznie, nie strukturalnie i funkcjonalnie - co nadrabia hiperbolizacja tych elementów, które skopiować potrafi; można zatem sadyzm uznać za szczególny przypadek opisywanego przez Freuda mechanizmu „reakcji upozorowanej” - gdy odrzucając jakąś tendencję z własnej głębokiej struktury psychicznej, w strukturze powierzchniowej przesadnie akcentuje się jej przeciwieństwo. W tym kontekście „zniknięcie” matki i poczucie bycia zrodzonym raczej z fantazji ojca niż z łona jego żony (Myśliwski 2011, 31) to po lacanowsku père-version sensu stricto - perwersja jako „zwrot ku ojcu”, po deleuzjańsku zaś - perwersyjna fantazja o ponownych narodzinach jako uwolnieniu $z$ edypalnego rozdarcia pomiędzy 
dwojgiem rodziców: narodzinach z samego tylko ojca (sadysta) albo z matki-dziewicy (masochista) (Deleuze 1989, 93-100).

Hipoteza sadyzmu pozwala pogłębić i zintegrować interpretację kilku charakterystycznych motywów powieści. Po pierwsze, ojciec jest niepiśmienny, nie umie się nawet podpisać, nie znamy też jego nazwiska, a nawet imienia - co stoi w rażącej sprzeczności z lacanowskim ujęciem signifiant Imienia Ojca jako klucza do systemu symbolicznego. Nie ignoruje jednak symboliczności jak psychotyk, przeciwnie - szanuje ja, a nawet nieporadnie czci oraz - zgodnie z tezami Finka o perwersji - próbuje wymusić zaistnienie symbolicznego tam, gdzie go brakuje: najpierw systematycznie udaje lekturę gazet (zostaje jednak zdemaskowany) (Myśliwski 2011, 158-165), potem wysyła syna na naukę do miasta, po której ten zostaje nauczycielem, chociaż nie widać, by miał do tego powołanie. Po drugie, mając niewiele do powiedzenia (słabość jego symboliczności obejmuje nie tylko bardziej zaawansowane pismo, lecz także elementarną mowę), ojciec wykazuje niezwykle silne pragnienie i wole - przy czym wbrew standardowym znaczeniom te wielokrotnie wracające w powieści terminy funkcjonuja tak, jakby były synonimami. W edypalnej metaforze ojcowskiej Imię Ojca, ustanawiające prawo, oddziela podmiot od irracjonalnego pragnienia matki, umożliwiając ustanowienie racjonalnej woli (rozumu praktycznego) - to podwojenie chcenia jest zaś kluczowe dla tradycyjnej filozofii moralności, prawa i polityki, a w dalszej perspektywie także dziejów (w sumie: dla heglowskiego ducha obiektywnego). Perwert natomiast utożsamia prawo (a zatem i wolę) z pragnieniem (sadysta: ojca, masochista: matki) - i tak właśnie wygląda to w Nagim sadrie. Po trzecie, chociaż ojciec nie jest sadysta w potocznym seksualnym sensie (nie znęca się fizycznie nad żona), są w tekście parabazy ujawniające impulsy tego rodzaju, szczególnie scena rytualnej wędrówki przez dziewięć mostów, gdy ojciec bije witką słaniająca się na nogach matkę - w imię magii i dla dobra chorego syna, więc niby poza uwarunkowaniami własnej osobowości, niemniej budząc sprzeciw szwagra, reprezentującego w obronie siostry zdroworozsądkowy neurotyczny opór wobec takiej przemocy - ale wyśmianego za to i wykluczonego przez wiejską wspólnotę. Dziekanowski przyjmuje to za dobrą monetę i uznaje, że postępowanie ojca nie jest przejawem sadyzmu, tylko seksualnego rytuału (Dziekanowski 1990b, 33), zarówno jednak samo w sobie (sadyzm to jest seksualny rytuał), jak i w szerszym kontekście wyjaśnienie to nie wydaje się trafne. „Szczęśliwe” zakończenie rozdziału, gdy po odprawionym rytuale ojciec z miłością zanosi matkę do domu, nie wyklucza interpretacji perwersyjnej: sadysta to nie potwór, który świadomie chce czynić zło - wprost przeciwnie, we własnym mniemaniu robi tylko to, co słuszne i konieczne, jeśli bije i dręczy, to przede wszystkim z miłości; ludową mądrość „Jeśli bije, to znaczy, że kocha” (Sewastianowicz 1988, 19) należy więc w takim kontekście uznać nie za cyniczna, tylko rzeczowo wykładająca pewną teorię podmiotowości. Do tej samej sfery należy fetyszystyczny zachwyt, jaki budzą ciało, a zwłaszcza włosy żony 
przed narodzeniem syna (Myśliwski 2011, 41-43): jak zwraca uwage Lacan, ofiary sadystów w fantazjach de Sade'a są nieskazitelnie i nierealistycznie piękne, bo estetyzacja - podobnie jak etyzacja (u Myśliwskiego: „konieczność” ratowania syna sadystycznym rytuałem) stanowi barierę przed osunięciem się w psychotyczną otchłań matczynej Rzeczy (do której zgodnie z naszą rekonstrukcją sadyście szczególnie blisko - i która oczywiście nie jest tożsama z faktyczną matką, chociaż dla sadysty ta ostatnia ma nieszczęście ją reprezentować, dlatego musi być usunięta z pola widzenia, sprowadzona do roli surogatki, gdy już utraci status bezdzietnego fetysza) (Lacan 1997, 57-84, 218-240).

Kolejna scena, w której podtekście odnaleźć można sadyzm, to wymuszanie na dziedziczce - za pomoca psychicznej przemocy - udostępnienia szlachetnego konia (Myśliwski 2011, 124-133, por. Dziekanowski 1993, 38-39). Gdyby analogiczna scena rozgrywała się między mężem a żoną, byłaby wyrazistym przykładem domowej przemocy (nawet jeśli nie fizycznej). Chiazm stosunków władzy - społecznie to dziedziczka jest stroną dominująca, nie ojciec narratora - zaciera tę wymowę, jednak nie wymazuje jej całkowicie. Sens tej konstrukcji nie ogranicza się jednak do eufemizmu, pozwala ona bowiem w pojedynczej i z pozoru prostej scenie znacznie poszerzyć strukturalny kontekst perwersji ojca. Dworem rządzi dziedziczka, chociaż tradycyjnie powinien oczywiście dziedzic, który pojawia się tylko w zwięzłych retrospekcjach. Z jednej strony we wsi panuje więc rodzaj matriarchatu, jaki Deleuze łączy z masochizmem, jako postać władcza dziedzic znacznie lepiej nadawałby się bowiem na edypalnego ojca niż ojciec faktyczny - zostaje jednak z wiejskiego uniwersum usunięty (koresponduje to $\mathrm{z}$ hipotezą „matriarchatu psychologicznego", jaki Leder dostrzega na polskiej wsi i we dworze) (Leder 2014, 102). Z drugiej - ojciec bohatera, w szokujący dla niego sposób stylizujący się w trakcie powrotu z miasta na jego sługę (sadza syna na miejscu dziedzica w powozie ciagniętym przez szlachetnego dworskiego konia), czyni zeń jakby syna dziedzica właśnie, nie własnego (w Pałacu podobna struktura zrealizowana jest z brutalnym naturalizmem: jako sugestia, że bohater począł się z gwałtu dziedzica na chłopce, co jej męża - formalnego ojca doprowadziło do samobójstwa) (Dziekanowski 1990b, 122-123). Podobny sens zdaje się mieć samo wysłanie syna „na naukę”, po której zaczytuje się książkami, o których mówi się, że nawet sam dziedzic ich wszystkich nie przeczytał (Myśliwski 2011, 84); Dziekanowski sugeruje, że książki owe to w powieści jeden z symboli matki (Dziekanowski 1990a, 29 -30) wtedy próby (perwersyjnie nieudane) opanowania ich przez dziedzica, a następnie przez bohatera byłyby literackim odpowiednikiem metafory ojcowskiej, w której Imię Ojca nazywa pragnienie matki (tu dosłownie: pragnienie biblioteki zostania przeczytaną i poddana interpretacji). Po przemianach narzuconych przez władzę ludową bohater zostaje wiejskim nauczycielem we dworze przejętym na szkołę i sam przejmuje dworskie książki; można by zatem uznać, że ojcowski plan symbolicznego uczynienia go dziedzicem powiódł się. 
Myśliwskiemu daleko jednak do prostej afirmacji peerelowskich przemian - bohater samokrytycznie stwierdza, że nie sprawdza się w roli nauczyciela i najprawdopodobniej niczego nie uczy, nie jest zatem symbolicznym „ojcem” swoich wiejskich uczniów, lecz raczej masochistycznym poddanym książek, których nie potrafi ogarnąć (Dziekanowski wprost chociaż jak zwykle nie w strukturalnym sensie - nazywa jego relację z książkami masochizmem). Inaczej możemy rzecz zinterpretować, uznając Nagi sad za utwór metafikcjonalny, taki, w którym pierwszoosobowy narrator jest metaforą autora (chociaż nie stanowi jego autobiograficznego przedstawienia na poziomie dosłownym): wtedy snucie wspomnień przez narratora stawałoby się odpowiednikiem pisania powieści przez autora, a jałowość egzystencji bohatera znosiłaby się nie w planie fabuły, tylko już w realnej twórczości, jak w Cqasie odnalezionym Prousta. W kontekście biografii twórczej Myśliwskiego wydaje się to prawdopodobne: Nagi sad to debiut autora trzydziestopięcioletniego, a więc raczej późny, wcześniej jednak Myśliwski długo pracował jako redaktor w wydawnictwie, a więc borykal się z książkami cudzymi - jak bohater, który kompulsywnie czuje się zmuszony czytać, chociaż wcale nie sprawia mu to przyjemności.

Nawet jeśli metaliteracka interpretacja Nagiego sadu jest trafna, sugerowanym przez nią rozwiązaniem, czyli przekroczeniem sprzeczności wiejskiej egzystencji dzięki sztuce, sam autor nie wydaje się usatysfakcjonowany, podejmuje bowiem podobne problemy w kolejnych powieściach, szukając jednak najwyraźniej dróg odmiennych - i nic dziwnego zresztą, zważywszy konwencjonalność takiego modelu. Pałac w znacznej mierze kontynuuje problematykę Nagiego sadu, opowiadając o chłopu, który po ucieczce pana w obliczu wojny fantazmatycznie „przejmuje” jego pałac, wcielając się w dziedzica (ucieczka dziedzica w Pałacu, podobnie jak jego zniknięcie w Nagim sadæie, strukturalnie odpowiada przy tym słabości postaci króla, która tak niepokoi w polskiej tradycji zarówno Sowę, jak i Rymkiewicza). Zdaniem Dziekanowskiego bohater - Jakub - to psychotyk, schizofrenik ogarnięty szaleństwem (Dziekanowski 1990b, 60, 92, 120 i 1994), chociaż chłop wobec pana był jak dziecko wobec ojca (Dziekanowski 1990b, 79), co sugerowałoby relację edypalna (Dziekanowski 1994, 10-16, 162), na dodatek zaś w sferze symptomatologii wykazuje sadyzm bądź sadomasochizm (Dziekanowski 1990b, 60-61, 130, i 1994, 165-168), podobnie zresztą jak bohaterowie późniejszego Kamienia na kamieniu (Dziekanowski 1990b, 207, 331). Ten ostatni trop konsekwentnie wydaje nam się najtrafniejszy, chociaż Dziekanowski nie rozważa go jako wyjaśnienia całości symptomów, wciąż ignorując perwersję jako strukturę, mimo że w izolacji zauważa poszczególne jej aspekty: np. to, że w psychice Jakuba współistnieja dwa plany - racjonalny i chorobowy (rozszczepienie w postaci typowej dla perwersji, 113), że jego halucynacje i urojenia różnią się od psychotycznych (107-109), że szczególnie istotne dla jego „sadyzmu” wydaja się kwestie superego, krzywdy i kary, poniżanie innych i żądanie posłuszeństwa (61, 130, 139, por. 291, 364), co odpowiada 
sadyzmowi jako hiperbolizującej superego karykaturze modelu edypalnego, nieobecnego w psychozie, a przejawiającej się w schmittowskim utożsamieniu arbitralnej woli z prawem w warunkach powieściowego stanu wyjątkowego: „jaśnie pan Jakub sam stanowi swoje prawo. [...] Prawem jaśnie pana jest samowola. Samowola [...] zdaje się być niewysychającym źródłem prawa” (Dziekanowski 1994, 152-153).

Hipoteza psychozy bohatera w sposób szczególny wpływa na interpretację świata przedstawionego: zrazu Dziekanowski uznaje, że tocząca się wojna to wyłącznie fantazja Jakuba (Dziekanowski 1990b, 84), dopiero potem niechętnie przyznaje, że może ona rezonować z realnymi wydarzeniami. To kontrowersyjna hipoteza - zważywszy realistyczne odniesienia do czasu historycznego, w tym do reformy rolnej i drugiej wojny światowej, w większości utworów Myśliwskiego (Nagi sad, Kamień na kamieniu, a także późniejsze od analiz Dziekanowskiego Widnokrag i Traktat o tuskaniu fasoli), bardziej naturalne wydaje się odniesienie także onirycznego Pałacu do realnych zdarzeń z czasu ostatniej wojny, nawet jeśli zostaja one poetycko przetworzone. Nie zmienia to oczywiście faktu, że wojna jest naznaczona sadyzmem, nie jest to jednak urojeniowy sadyzm psychotyka, tylko rzeczywisty sadyzm perwertów - choć nie autora: dyskrecja, z jaką Myśliwski opisuje wojnę, nadużywając wręcz elips i eufemizmów, dowodzi, że jak typowy neurotyk czuje się perwersyjnym nadmiarem rozkoszy nie tylko przerażony, lecz również zażenowany - w przeciwieństwie do Rymkiewicza, który zwłaszcza w Kinderszenen (ale i już w Wieszaniu) ekshibicjonistycznie eksponuje radość, jaką niesie mu detaliczne opisywanie rzeczywistych masakr.

Agrarna rewolucja, która według diagnozy Ledera została „prześniona”, w wersji Dziekanowskiego miałaby zatem być „przehalucynowana” przez psychotyka. Dziekanowski wprawdzie odnotowuje, a nawet miejscami refrenicznie powtarza, że osobowościowe problemy Jakuba to odzwierciedlenie konfliktów społecznych wynikających z klasowej struktury wsi (Dziekanowski 1990b, 74-76), diagnozuje jednak, że opozycję pana i służącego da się przezwyciężyć tylko w urojeniu (96), narzucając interpretowanej powieści konserwatywny fatalizm, którego my w niej nie widzimy (Myśliwski, owszem, nieraz przedstawia fatalistycznie nastawionych bohaterów, zarazem jednak usilnie poszukuje „linii ucieczki” z wiejskiego świata fatum). Po części ta różnica interpretacji wynika być może z różnicy przyjętych metod: Dziekanowski, najbliższy w swojej psychoanalitycznej poetyce Melanii Klein, uprawia hermeneutykę obrazowych symboli - kulminujących w arcysymbolu śmierci. Wyraz „śmierć” powtarza się w analizach Dziekanowskiego w obsesyjnych nieraz poliptotonach (np. 266, 302-304, 334), mających uspójnić rozbiegające się w różnych kierunkach interpretacje innych symboli; owo puste $\mathrm{w}$ zasadzie signifiant czyni to jednak jedynie afektywnie, w zastępstwie brakujących pojęć. Naszym zdaniem lacanowski strukturalizm pozwala ten sam materiał uporządkować właśnie pojęciowo i dzięki temu choć paradoksalnie, skoro strukturalistów nieraz oskarżano o ignorowanie dziejowej 
diachronii - ukazać jego historyczną dynamikę poza „wiecznym powrotem” mitologizujących obrazów, czyli krytycznie przeanalizować sadyzm jako pewien szczególny stosunek do władzy i prawa, a nie tylko kontemplować go jako przemoc zawsze dążącego w to samo miejsce popędu śmierci, jak jawił się psychoanalizie przedlacanowskiej (znamienne, że ten klasyczny model popędu śmierci wykorzystuje Sowa do opisu psychiki szlacheckiej - Sowa 2011, 390_ 393).

Pisząc pseudoheglowskim językiem o panu i słudze w Pałacu, Dziekanowski uznaje ich za wzajemnie dopełniających się, wręcz - w planie urojeniowym - za przeciwne bieguny tej samej osoby (Dziekanowski 1990b, 124, 140), co można uznać za kolejny argument za interpretacja tej powieści poprzez kategorię perwersji, dysonansowo dopełniają się bowiem sadysta z masochista, mający „po połowie” edypalnej symboliczności (w ich wzajemnej relacji połowy te jednak nie sumują się raczej do całości, lecz mnożą przez siebie, dając w efekcie dysfunkcjonalną ćwierć), a nie neurotyk z psychotykiem (pierwszy dysponuje całością rozumu, drugiemu go całkiem brak, więc asymetria jest zbyt duża dla relacji dwóch odmiennych, ale równoprawnych podmiotów). Uruchamiając w tym kontekście dialektykę autentycznie heglowską, uznać można, że ta diada odpowiada figurze oddriaływania wrajemnego z końca logiki obiektywnej Hegla - figurze, w której przechodzi ona w subiektywną (podmiotowa) logikę pojęcia, z konieczności przechodząc w wolność (Hegel 1968, 328-340). Dialektyka sadyzmu i masochizmu mogłaby zatem zrodzić wolną i spójną podmiotowość i takiej zdaje się szukać Myśliwski w kolejnych powieściach, w Widnokregu, gdzie na granicy autobiografizmu eksperymentuje $z$ mieszczańską nerwica, najbliższą klasycznemu modelowi Freuda, i w Traktacie o tuskaniu fasoli, gdzie narrator-sierota jako ofiara, ale i członek machiny wojennej przypomina nomadę z Tysiaca plateau Deleuze’a i Guattariego... 


\section{Wykaz literatury}

Arendt, Hannah. 2003. O rewolucji. Tłum. Mieczysław Godyń. Warszawa: Czytelnik. Chernetsky, Vitaly. 2008. „Nationalizin Sacher-Masoch: A Curious Case of Cultural Reception in Russia and Ukraine". Comparative Literature Studies 45, nr 4: 471-490.

Deleuze, Gilles. 1989. Masochism: Coldness and Cruelty. Tłum. Jean McNeill, New York: Zone Books.

Dybel, Paweł. 1997. Recenzja książek: W imie Ojca i Syna, Życie Jaśnie Pana, Życie w śmierci Czesława Dziekanowskiego. Pamiętnik Literacki 88/1: 213-220.

Dziekanowski, Czesław. 1990a. „Narodziny ojca: Psychoanalityczna interpretacja Nagiego sadu”. Twórczość 5: 29-51.

Dziekanowski, Czesław. 1990b. Proza ,życia w śmierci”: Psychoanaliza twórczości powieściowej Wiesława Myśliwskiego. Białystok: Dział Wydawnictw Filii UW.

Dziekanowski, Czesław. 1993. W imie Ojca i Syna. Warszawa: Semper.

Dziekanowski, Czesław. 1994. Życie jaśnie pana. Warszawa: Semper.

Fink, Bruce. 2002. Kliniczne wprowadzenie do psychoanalizy lacanowskiej: Teoria i technika. Tłum. Lukasz Mokrosiński. Warszawa: Andrzej Źórawski.

Freud, Sigmund. 2007. Fetyszyzm i Rozszczepienie ,ja” w procesie odparcia. Tłum. Robert Reszke. W Freud, Sigmund, Psychologia nieświadomości, Warszawa: KR.

Hegel, Georg Wilhelm Friedrich. 1968. Nauka logiki, t. II. Tłum. Adam Landman. Warszawa: PWN.

Lacan, Jacques. 1989. „Kanta Sadem”. Tłum. Tadeusz Komendant. Twórczość 8: 38-58.

Lacan, Jacques. 1997. The Ethics of Psychoanalysis: The Seminar of Jacques Lacan Book VII. Tłum. Dennis Potter. New York: Norton.

Leder, Andrzej. 2014. Prześniona rewolucja: Ćwiczenia z logiki bistorycznej. Warszawa: Wydawnictwo Krytyki Politycznej.

Myśliwski, Wiesław. 2011. Nagi sad. Kraków: Znak.

Rymkiewicz, Jarosław Marek. 1983. Wielki ksiaże z dodaniem rozważan o istocie i praymiotach ducha polskiego. Warszawa: PIW.

Rymkiewicz, Jarosław Marek. 2007. Wiesqanie. Warszawa: Sic!

Schmitt, Carl. 2015. Legalność i prawomocność. Tłum. Bogdan Baran. Warszawa: Aletheia.

Sewastianowicz, Ireneusz. 1989. Bije, znaçy kocha. W Bije, znaçy kocha: Zbiór reportaṡy. Warszawa: LSW.

Sowa, Jan. 2011. Fantomowe ciało króla: Peryferyjne zmagania z nowoczesna forma. Kraków: Universitas.

Sulej, Dominik. 2012. „Witkacego i Sade’a Lacanem”. Recenzja książki Samoreprezentacje: Sade i Witkacy Łucji Iwanczewskiej. Teatr. http://www.teatrpismo.pl/czytelnia/3/witkacego_i_sadea_lacanem/

Žižek, Slavoj. 2011. Carl Schmitt w czasach postpolityki. Tłum. Piotr Płócienniczak. W Carl Schmitt. Wyzwanie polityczności, red. Chantal Mouffe. Warszawa: Wydawnictwo Krytyki Politycznej. 
Zbigniew Jazienicki - absolwent polonistyki i dziennikarstwa. Doktorant Instytutu Literatury Polskiej UW. Przygotowuje pracę doktorską poświęconą postsekularyzmowi Jarosława Marka Rymkiewicza.

Jan Potkański - profesor w Zakładzie Literatury XX i XXI wieku na Wydziale Polonistyki UW, autor książek: Sobowtór. Różewicz a psychoanaliza Jacquesa Lacana i Melanii Klein (2004), Sens nowoczesnego wiersza. Wersyfikacja Białoszenskiego, Pryybosia, Mitosza i Herberta (2004), Parabazy wplywu. Iwaszkiewicz - Bloom - Lacan (2008), Epoka spojrzenia. Literatura i spoleczeństwo nowego kapitalizmu (2014).

\section{DANE ADRESOWE:}

Instytut Literatury Polskiej

Wydział Polonistyki UW

ul. Krakowskie Przedmieście 26/28

00-927 Warszawa

EMAIL: jan2@go2.pl

CYTOWANIE: Jazienicki, Zbigniew, Potkański, Jan. Sadyzm w Nagim sadzie. Perwersja jako struktura polskości. Praktyka Teoretyçna 4(22): 152-170.

DOI: $10.14746 /$ prt.2016.4.8

AUTHORS: Zbigniew Jazienicki, Jan Potkański

TITLE: Sadism in The Nude Orchard. Perversion as the structure of Polishness

ABSTRACT: The first part of the article investigates perspective of perversion employed in the analysis of the Polish collective psychology in its pathologies identified in books of Jan Sowa, Andrzej Leder and Jarosław Marek Rymkiewicz. The category of perversion itself is reconstructed chiefly after works of Jacques Lacan and Gilles Deleuze. In our opinion, the cultural model of Pole is the pervert. Depending on the social class, he is a sadist or a masochist, as opposed to a psychotic or a classical Oedipal neurotic. The category of perversion allows for the explanation of an ambivalent relationship between the Polishness and the State; the relationship which is neither a simple rejection (such as a psychosis) nor an unequivocal affirmation (such as a neurosis).

The second and the third part are case-studies: in a collective psychology of the heroes of Rymkiewicz's essays and in an individual psychology of the heroes of The Nude Orchard (pol. Nagi sad) by Wiesław Myśliwski. This juxtaposition shows the difference in perception of the 
same phenomenon, i.e. sadism - the difference between the point of view from within the mind affirmatively indentifying with the perverse attitude (Rymkiewicz) and the distanced point of view of a neurotic (Myśliwski). It also allows for grasping the isomorphism of structures behind these twoperceptions.

KEYWORDS: Wiesław Myśliwski, Jarosław Marek Rymkiewicz, Jacques Lacan, Gilles Deleuze, psychoanalysis, perversion, sadism, law 